14.10

\title{
Широкопольная флуоресцентная микроскопия в доклинических исследованиях биомедицинских материалов, скаффолдов и биомедицинских клеточных продуктов
}

\author{
(c) М.Н. Егорихина, ${ }^{1}$ Д.Я. Алейник, ${ }^{1}$ И.Н. Чарыкова, ${ }^{1}$ Ю.П. Рубцова, ${ }^{1}$ В.В. Юдин, ${ }^{2}$ А.Г. Морозов ${ }^{2}$ \\ ${ }^{1}$ Приволжский исследовательский медицинский университет, \\ 603005 Нижний Новгород, Россия \\ ${ }^{2}$ Институт металлоорганической химии им. Г.А. Разуваева РАН, \\ 603137 Нижний Новгород, Россия \\ e-mail: egorihina.marfa@yandex.ru
}

Поступило в Редакцию 16 января 2020 г.

В окончательной редакции 25 февраля 2020 г.

Принято к публикации 25 февраля 2020 г.

\begin{abstract}
Представлены результаты исследований взаимодействия клеток с различными материалами и изделиями из них, предназначенными для биомедицинского использования. Показано, что широкопольная флуоресцентная микроскопия позволяет оценить цитотоксичность образцов, жизнеспособность, морфологию и пролиферативную активность клеток в процессе взаимодействия с исследуемыми образцами, а также адгезию, миграцию и распределение клеток как на поверхности, так и в структуре скаффолдов и биомедицинских клеточных продуктов. Методы флуоресцентной микроскопии делают возможными прижизненные исследования взаимодействия клеток с материалами без дополнительной обработки и разрушения образцов.
\end{abstract}

Ключевые слова: флуоресцентная микроскопия, титановый сплав, полилактид, пористый полимер, скаффолд, биомедицинский клеточный продукт.

DOI: $10.21883 / J T F .2020 .09 .49695 .15-20$

\section{Введение}

Развитие регенеративной медицины неразрывно связано с поиском новых материалов. Инновационные материалы используются самостоятельно в качестве медицинских изделий или служат основой для скаффолдов и биомедицинских клеточных продуктов (БМКП). Материалы, предназначенные для биомедицинского использования, чрезвычайно разнообразны по характеристикам, составу и свойствам: это металлы, биокерамика, отверждаемые синтетические полимеры, децеллюляризованные матриксы, гидрогели (синтетические/природные) и др. Материалы играют ключевую роль в процессах регенерации, обеспечивая успешные клеточные события и интеграцию конструкций в организм пациента. В связи с этим важно еще на этапе разработки материалов оценить их взаимодействие с клетками. Не вызывает сомнения, что если при взаимодействии материала с клетками на модели in vitro материал негативно влияет на их морфологию и функциональную активность, то вряд ли в будущем возможно ожидать положительного эффекта при его применении в клинической практике. Доклинические исследования на модели in vitro в большинстве случаев ограничиваются исследованием цитотоксичности материала, как правило, косвенными методами, например, с помощью широко распространенного МТТ-теста. Визуальная прижизненная оценка состояния и функционирования клеток на материалах с помощью стандартных методов световой и фазовоконтрастной микроскопии затруднена, так как чаще всего эти объекты не прозрачны. Поэтому более детальное исследование, такое, как характеристика адгезии клеток, распределение их на поверхности и/или в структуре материала, жизнеспособность и изменение пролиферативной активности в процессе взаимодействии с материалами, как правило, требуют белее сложных методов исследования [1], связанных с гибелью клеток и/или их отделением от матрицы и ее разрушением. Дополнительные манипуляции могут приводить к потере клеток и соответственно к возникновению серьезных погрешностей при анализе результатов. Все вышеизложенное требует подходов, обеспечивающих комплексную прижизненную оценку взаимодействия поверхностно-зависимых клеток с материалами, скаффолдами или БМКП без сложной обработки и привлечения дополнительных методов исследования.

\section{1. Материалы и методы}

\section{1. Общие принципы работы}

Все манипуляции по выделению и культивированию клеток проводили в помещении класса С в стерильных условиях ламинаров (класса А) в лаборатории биотехнологий ФГБОУ ВО ПИМУ Минздрава России. Ростовые среды в процессе культивирования клеток, материалов, 


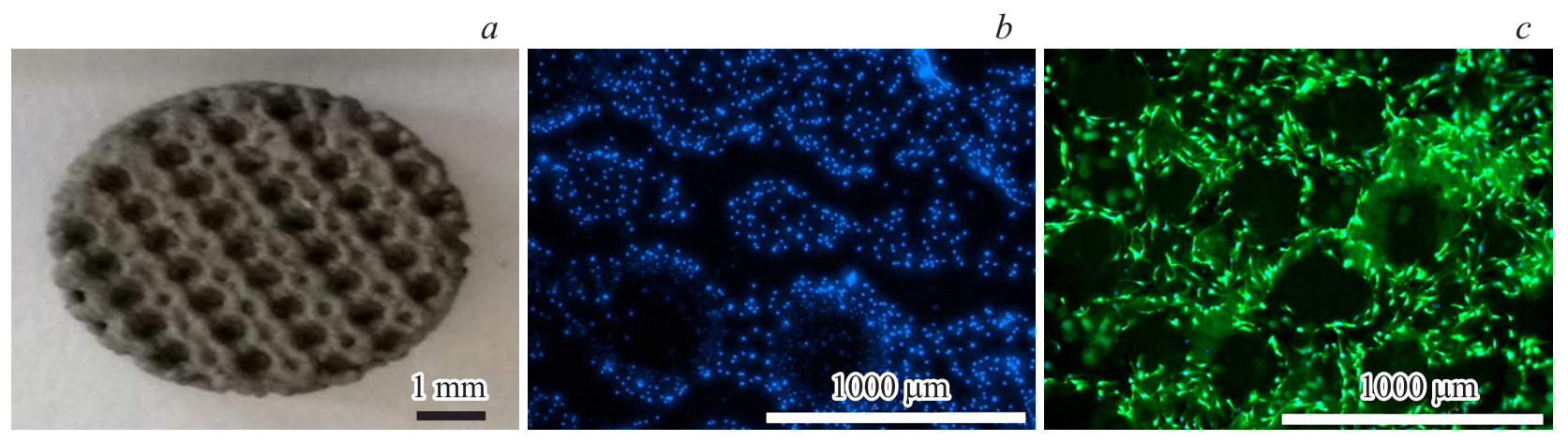

Рис. 1. $a-$ внешний вид образцов из титанового сплава с пористым микрорельефом поверхности; $b-$ ядра клеток, адгезировавших к поверхности образцов из титанового сплава (окрашивание Hoechst 3334), повторяют топографию поверхности образца; $c$ - клетки, иммобилизованные на поверхности образца, окрашенные флуорохромом Сalcein AM - жизнеспособные клетки характерной веретеновидной формы.

скаффолдов и БМКП регулярно контролировали на стерильность, контаминацию микоплазмами и вирусами, наличие грибковой флоры. Протокол исследования был одобрен локальным этическим комитетом и утвержден Ученым советом ФГБОУ ВО ПИМУ Минздрава России. Каждый пациент, представивший материал, дал добровольное информированное согласие на его использование в исследованиях.

\section{2. Выделение и культивирование мезенхимальных стволовых клеток человека}

Мезенхимальные стволовые клетки выделяли из жировой ткани человека (Human Adipose-derived Stem Cells - hASCs) c помощью тепловой ферментативной обработки коллагеназой (Sigma-Aldrich, Germany) и культивировали в полной ростовой среде (среда $\alpha$-MEM, $20 \%$ телячьей эмбриональной сыворотки (ТЭС), глутамин, антибиотики пенициллин/стрептомицин) при абсолютной влажности, $+37^{\circ} \mathrm{C}, 5 \% \mathrm{CO}_{2}\left(\mathrm{CO}_{2}\right.$ инкубатор, „Sanyo“, Япония). Были использованы среды и реактивы фирмы „Gibcoß) (UK), пластик фирмы „Costar“ (USA). По достижении субконфлюэнтного монослоя (60-70\%) культуру пересевали. Для экспериментов брали культуры 3-4 пассажа. В работе использовали hASCs c подтвержденным дифференцировочным потенциалом в адипогенном, остогенном и хондрогенном направлениях. Жизнеспособность клеток культуры перед вводом в эксперимент составляла 98-99\%. Иммунофенотип клеток был характерен для мезенхимальных стволовых клеток (MSCs): клетки экспресситровали CD90, CD105, CD 73, CD 44, CD 10 и не экспрессировали CD 45, CD 14, CD 34, HLA DR. Характеристика культур соответствовала критериям, определенным Международным Обществом Клеточной Терапии (ISCT) для мезенхимальных стволовых клеток.

\section{2. Материалы}

В настоящей работе исследованы следующие образцы: № 1 - материал из титанового сплава, использующийся для изготовления костных имплантатов с упорядоченным пористым микрорельефом поверхности (рис. $1, a)$; № 2 - аморфный полиэфирный материал на основе поли-D,L-молочной кислоты для изготовления биосовместимых имплантов с малым сроком резорбции, полученный по оригинальной методике из пищевой молочной кислоты (разработка ИМХ РАН); № 3 полукристаллический полиэфирный материал на основе поли-L-молочной кислоты для изготовления биосовместимых имплантов с пролонгированным сроком резорбции (разработка ИМХ РАН); № 4 - костнозамещающий скаффолд из пористого полимерного материала на основе олигокарбонатдиметилакрилата ОКМ-2 (разработка ИМХ РАН); № 5 - костнозамещающий скаффолд на основе гидроксиапатита, коллагена и сульфатированных гликозаминогликанов с сохраненной естественной архитектоникой; № 6 - БМКП - эквивалент кожи (разработка ФГБОУ ВО „ПИМУ“ Минздрава России) конструкция, сформированная на основе гидрогелевого скаффолда из природных биополимеров: фибриногена в составе криопреципитата плазмы крови, коллагена I типа и культивированных аллогенных hASCs, введенных в структуру скаффолда в процессе формирования.

\section{1. Широкопольная флуоресцентная микроскопия}

Широкопольную флуоресцентную микроскопию (ШФМ) проводили с использованием имиджера Cytation 5 с программным обеспечением Gen5 Imedge+ (BioTek, USA). В настоящей работе использовали витальное окрашивание клеток флуорохромами: Calcein AM (BD Pharmingen $\left.{ }^{\mathrm{TM}}\right)$ - флуорохром, гидролизуемый эндогенными клеточными эстеразами и являющийся маркером жизнеспособных клеток (длина волны 


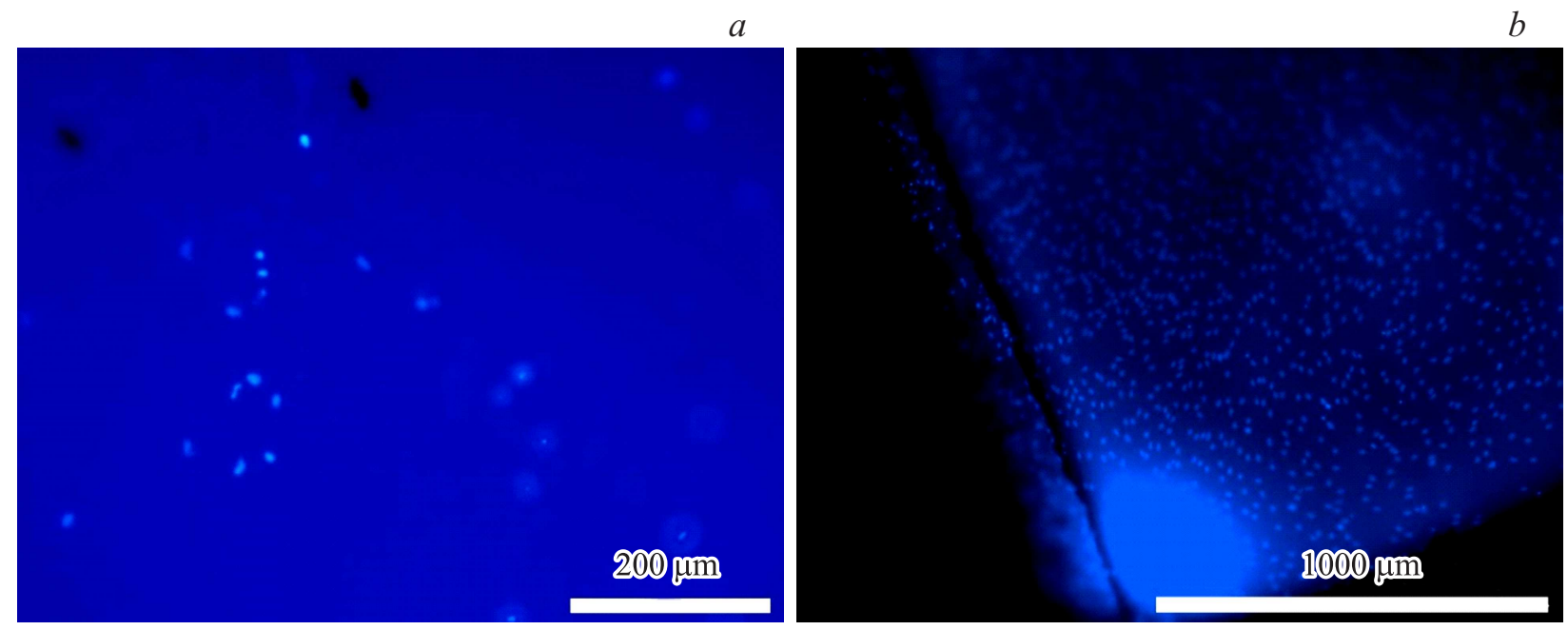

Рис. 2. Ядра клеток, окрашенные Ноеchst 3334 на поверхности образцов из полиэфирного материала: $a-24$ h культивирования, $b-96$ к культивирования.

возбуждения $477 \mathrm{~nm}$, длина волны эмиссии $525 \mathrm{~nm})$, и Hoechst 3334 (BD Pharmingen ${ }^{\mathrm{TM}}$ ) - флуорохром, обладающий высокой специфичностью к двухцепочечной молекуле ДНК (длина волны возбуждения $377 \mathrm{~nm} \mathrm{и}$ длина волны эмиссии $477 \mathrm{~nm}$ ). Окрашивание образцов проводили в соответствии с протоколом производителя.

\section{3. Результаты и обсуждение}

Титановые сплавы широко используются для изготовления имплантов. При разработке и исследовании свойств таких конструкций одним из важнейших является вопрос о биосовместимости и свойствах поверхности изделия [2]. Для исследования возможностей ШФМ при изучении взаимодействия поверхностно зависимых клеток с титановыми сплавами на образцы материала № 1 из титанового сплава со сложным рельефом поверхности были высеяны hASCs с плотностью 20 thous $/ \mathrm{cm}^{2}$ и через $48 \mathrm{~h}$ окрашены флуорохромами. Контролем служила эта же культура, культивируемая в стандартных условиях. При исследовании образцов, окрашенных Ноechst 33342, фиксировали выраженную, но неравномерную адгезию клеток к поверхности (рис. 1,b). При этом зоны с выраженной адгезией клеток четко соответствовали топографии поверхности образцов. Использование Calcein AM продемонстрировало жизнеспособность клеток, культивируемых на образцах в процессе исследования, что подтверждало отсутствие их цитотоксического воздействия на клетки. На всех этапах исследования клетки сохраняли веретеновидную форму, характерную для MSCs, культивируемых на плоской поверхности (рис. $1, c)$, что соответствовало контролю.

Полилактид - синтетический полимер, различные соединения которого достаточно широко используются в медицинских целях при изготовлении скаффолдов, систем доставки лекарств, устройств фиксации костей, хирургического шовного материала [3]. Материалы на основе полимолочной кислоты очень разнообразны, но постоянно разрабатываются новые соединения на основе полилактидов для улучшения таких характеристик как скорость биодеградации, прочностные характеристики и др., которые требуют проведения доклинических исследований [4]. Для оценки свойств на образцы полилактидного материала № 2 были высеяны hASCs с плотностью 10 thous $/ \mathrm{cm}^{2}$. При использовании ШФМ уже через $24 \mathrm{~h}$ на образцах визуализировались редко и хаотично распределенные ядра клеток, адгезировавшихся к поверхности (рис. 2,a). Через $96 \mathrm{~h}$ исследования фиксировали равномерное распределение клеток по всей поверхности образцов с высокой степенью плотности (рис. 2, $b$ ). Полученные результаты свидетельствовали об отсутствии цитотоксичности материала, хорошей адгезии клеток к его поверхности и сохранении клетками пролиферативной активности при культивировании на поверхности образцов.

Костнозамещающие материалы и скаффолды чрезвычайно разнообразны по структуре, составу и свойствам [5]. Исследуемые костнозамещающие скаффолды (№ 4, № 5) имели различную природу, но оба характеризовались высокой степенью пористости. Пористые скаффолды после имплантации в область дефекта предполагают заселение клетками, мигрирующими из окружающих тканей. Топография поверхности скаффолда, размеры, количество пор и межпоровых канальцев могут оказывать непосредственное влияние на клеточную миграцию, пролиферацию, формирование межклеточных контактов и дифференцировку клеток. Развитая система пор должна создавать условия для успешных клеточных событий и, как следствие, обусловливать возможность васкуляризации и ремоделирования регенерирующей ткани [6], поэтому при проведении доклинических исследований пористых материалов одной 


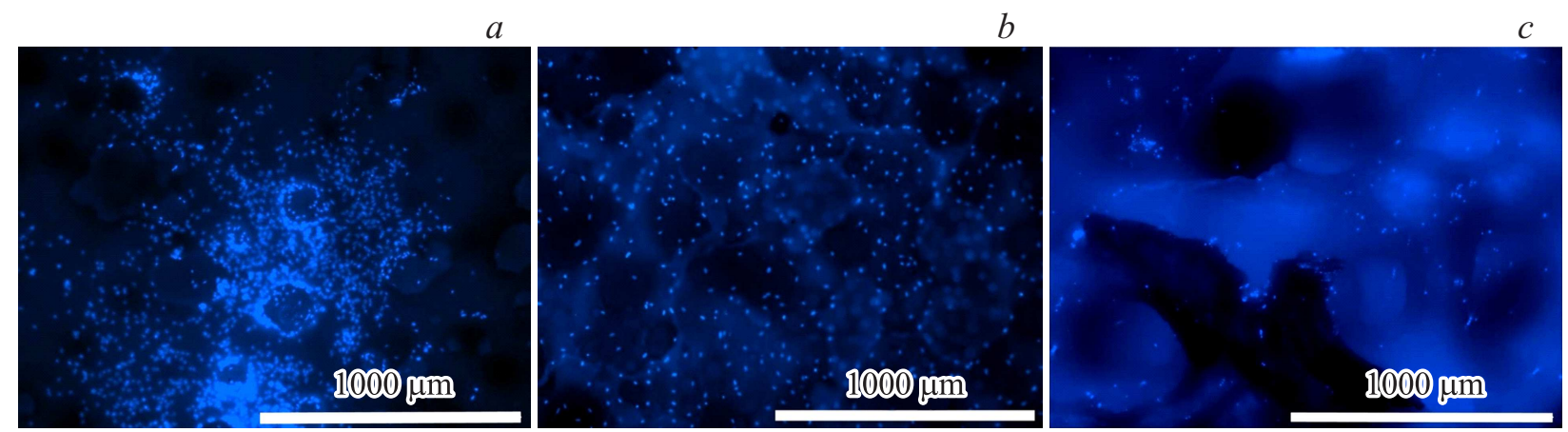

Рис. 3. Ядра клеток (окрашивание Ноеchst 3334) на поверхности образца № 4 (a) и на внутренней структуре костнозамещающих пористых скаффолдов: $b$ - скаффолд № 4; $c$ - скаффолд № 5, сшитое изображение Z-stack.

из основных задач является характеристика поведения клеток не только на поверхности, но и в структуре образцов. Прежде всего имеет значение способность клеток заселять внутреннюю поверхность структурных элементов скаффолдов.

Известно, что клетки активно мигрируют по направлению из зоны высокой плотности в свободную зону [7], поэтому для исследования миграции клеток в пористых образцах использовали достаточно высокую исходную плотность hASCs - 40 thous $/ \mathrm{cm}^{2}$. Через 12 и $48 \mathrm{~h}$ культивирования образцы окрашивали флуорохромом Hoechst 33342. При исследовании скаффолда № 4 использовали метод ШФМ с микрофотосьемкой выбранного участка. Результаты исследований показали, что спустя $12 \mathrm{~h}$ клетки визуализировались на поверхностных структурах образца и имели неравномерное распределение (рис. 3,a). Было установлено, что спустя $48 \mathrm{~h}$ клетки мигрировали в структуру образца и равномерно заселяли внутренние структурные элементы (рис. $3, b$ ). Адгезивные свойства поверхности материалов на основе диметилакрилата, жизнеспособность и пролиферативная активность клеток при их культивировании на них продемонстрированы нами ранее [8].

При исследования образцов скаффолда № 5 была использована функция Z-stack, позволяющая проводить послойную микрофотосъемку объектов с фиксацией глубины слоя и последующей сшивкой микрофотоснимков. Спустя $12 \mathrm{~h}$ после высева клетки адгезировали на поверхностных структурах и обнаруживались на глубине не более $150 \mu \mathrm{m}$. Зафиксировано, что через $48 \mathrm{~h}$ после посева клетки мигрировали в толщу скаффолда на глубину до $742 \mu \mathrm{m}$ (рис. 3,c). Следует отметить, что клетки заселяли структурные элементы скаффолда № 5 неравномерно и с меньшей плотностью по сравнению со скаффолдом № 4.

При проведении исследований методом ШФМ на представленных образцах визуализировались не только ядра клеток, но и внутренняя архитектоника скаффолдов. Визуализация структурных элементов скаффолдов в данном случае связана с наличием фонового свечения, часто возникающего при проведении флуоресцентной микроскопии за счет различных оптических явлений (например, преломление, отражение, рассеяние) при взаимодействии световых волн (волны возбуждения и эмиссии) с материалом и структурными элементами скаффолдов. Последнее позволило оценить адгезию клеток к внутренним структурным элементам скаффолдов, визуализировать распределение клеток относительно этих элементов и охарактеризовать плотность заселения клетками структуры скаффолдов. Использование функции Z-stack сделало возможным оценить глубину миграции клеток в структуру скаффолда за определенный период времени, что, по сути, является характеристикой скорости миграции клеток в скаффолд и может стать высокоинформативным показателем в сравнительных исследованиях.

Еще один класс объектов для регенеративной медицины - биомедицинские клеточные продукты (БМКП), состоящие из матрицы-носителя (скаффолда) и клеточного компонента. При исследовании характеристик клеточного компонента БМКП часто используют различные методы выделения клеток. Однако процесс отделения клеток от матрицы, как правило, требует ее разрушения, приводит к потере части клеток и может отрицательно воздействовать на характеристики оставшихся. Оптимальными в этом случае являются методы, позволяющие оценить основные параметры клеток (морфологию, жизнеспособность, распределение, концентрацию и др.) непосредственно в структуре матрицы-носителя.

Окрашивание образцов БМКП (№ 6) флуорохромом Calcein AM показало, что hASCs, культивируемые в образцах, жизнеспособны, проявляют трехмерный рост, имеют множественные отростки, формирующие межклеточные контакты и клеточную сеть (рис. 4, a), что характерно для трехмерного культивирования клеток в гидрогелевых скаффолдах $[9,10]$. Для визуализации клеточного компонента таких БМКП можно эффективно использовать и ряд других флуорохромов, например, мембранный флуорохром Lipophilic Tracers-DiO DiOC14(3) Hydroxyethanesulfonate (рис. 4, $b$ ). В то же время использование таких флуорохромов, как Calcein AM и Tracers$\mathrm{DiO}$, флуоресцирующих в цитоплазме и на мембране 

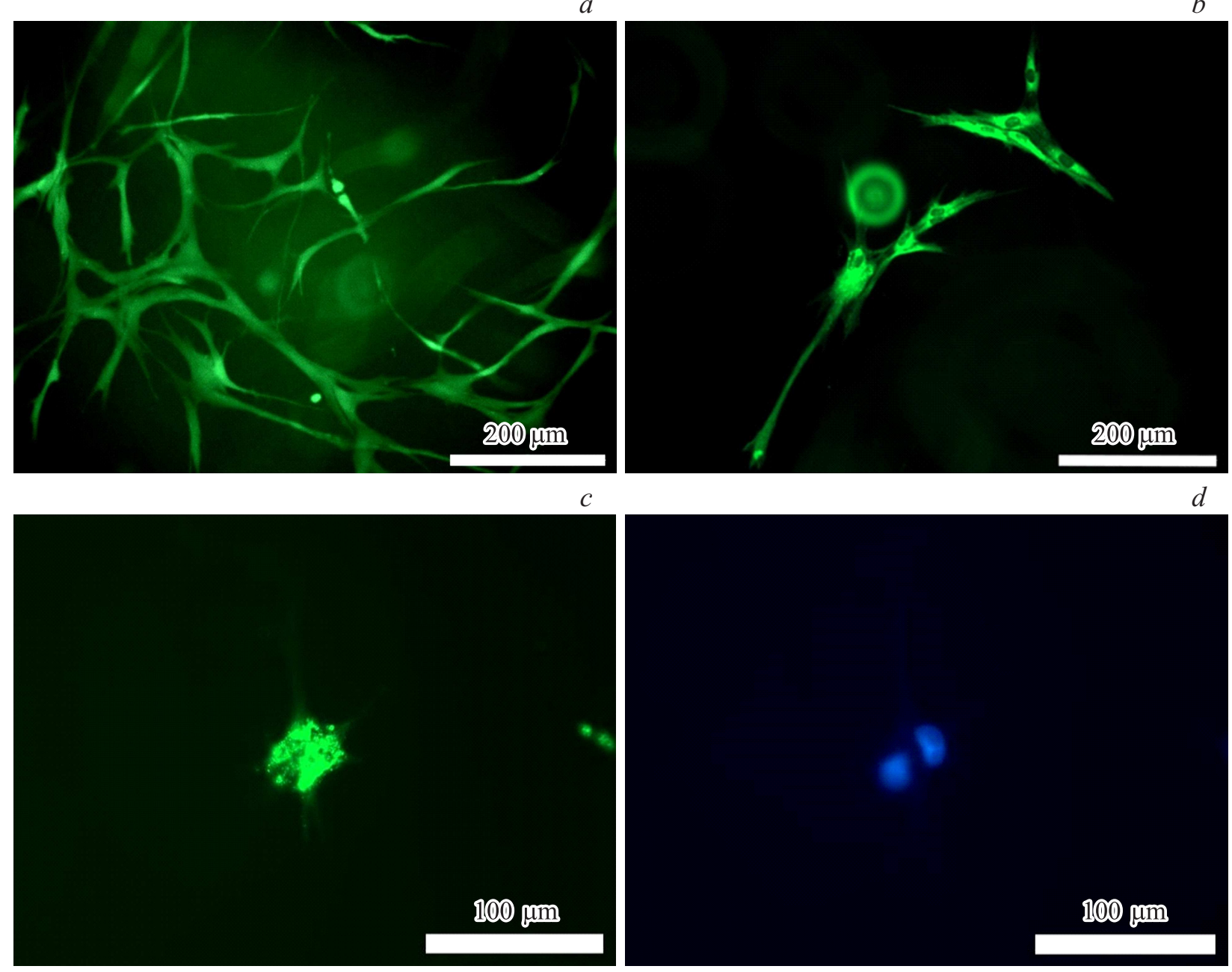

Рис. 4. Клетки, инкапсулированные в гидрогелевый скаффолд: $a-$ клеточная сеть, образованная жизнеспособными клетками в структуре скаффолда, шестые сутки культивирования, окрашивание Calcein AM; $b$ - клетки с характерной для трехмерного культивирования морфологией с множественными отростками, третьи сутки культивирования клеток в скаффолде, окрашивание Tracers-DiO; $c$ - близкорасположенные клетки в структуре скаффолда, окрашивание Tracers-DiO; $d-$ близкорасположенные клетки в структуре скаффолда — ядерный краситель Ноechst 3334.

клеток, часто не обеспечивает возможность идентифицировать близкорасположенные или делящиеся клетки (рис. 4,c). Применение ядерных красителей, таких, как Hoechst 33342, позволяет решить эту проблему (рис. $4, d$ ).

При проведении доклинических исследований описанных выше материалов и продуктов биомедицинского назначения часто не достаточно качественного анализа. Для решения некоторых задач, например, для оценки пролиферативной активности клеток, культивируемых на образце, необходим количественный анализ. Проведение прямого количественного анализа клеток, иммобилизованных на поверхности образцов с использованием ШФМ, не вызывает затруднений. Для этой цели образцы обычно окрашивают ядерными флуорохромами, а затем проводят прямой подсчет количества ядер клеток в нескольких полях зрения [11]. Например, на образцы полилактидных пленок (№ 3) были высеяны клетки с исходной плотностью 10 thous $/ \mathrm{cm}^{2}$. В контрольные сроки (24, 96 и $144 \mathrm{~h}$ после посева клеток) образцы окрашивали Hoechst 33342, на каждом образце проводили съемку 10 полей зрения, количество клеток пересчитывали на $1 \mathrm{~mm}^{2}$. Было установлено, что через $24 \mathrm{~h}$ клетки адгезировали к поверхности образцов. Плотность клеток, культивируемых на образцах, за 5 суток увеличилась более чем в 3 раза. Полученные результаты показали, что исследуемый полилактидный материал не оказывал отрицательного влияния на пролиферативную активность клеток (рис. 5,a), и свидетельствовали об отсутствии цитотоксичности образцов и хороших адгезивных свойствах их поверхности. Следует отметить, что исходная плотность клеток при проведении таких исследований не должна быть слишком высокой. Избыточная исходная плотность может приводить к быстрому 

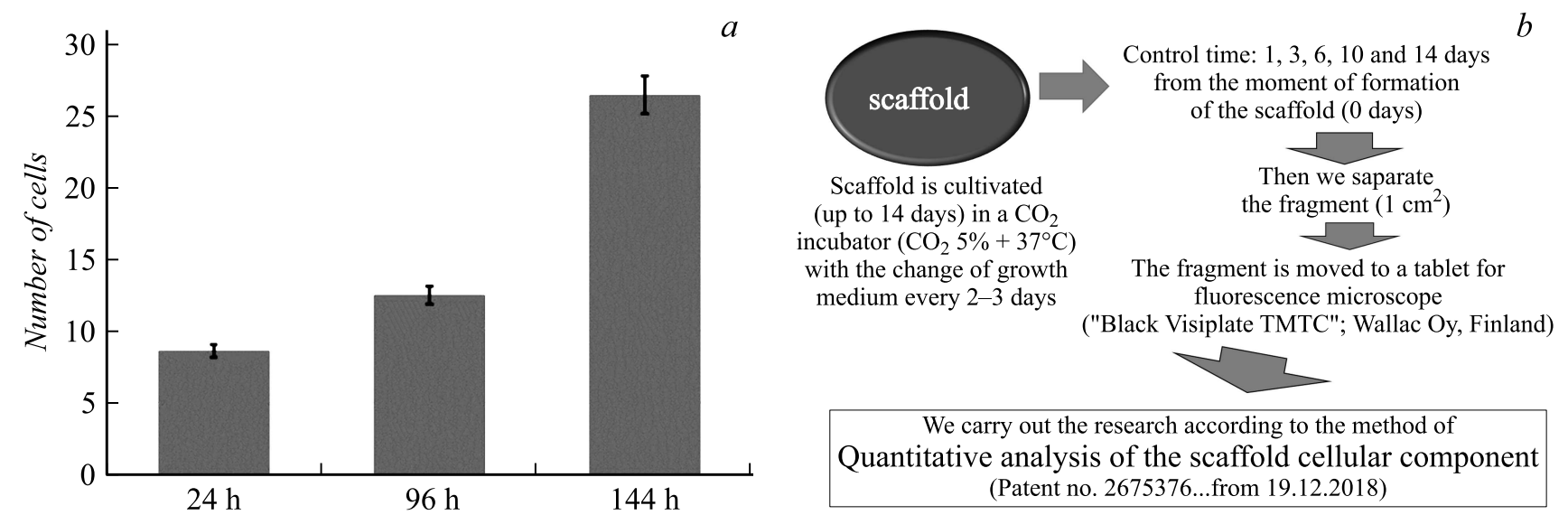

Рис. 5. Количественный анализ клеток: $a$ - оценка пролиферативной активности клеток, культивируемых на поверхности образцов из полилактида; $b-$ схема оценки пролиферативной активности клеток, культивируемых в трехмерных скаффолдах.

формированию конфлюэнтного монослоя или слишком высокой плотности клеточной сети в скаффолде/БМКП, что, в свою очередь, будет снижать пролиферативную активность клеток за счет эффекта торможения, зависимого от плотности [12]. Последнее неизбежно приведет к искажению оценки процесса пролиферации.

Задача количественного анализа плотности клеток значительно усложняется, если они расположены не только на поверхности образцов, но и внутри, например, инкапсулированы в структуру скаффолда или БМКП. Нами разработан достаточно простой способ количественного анализа клеточной составляющей скаффолда, позволяющий оценить, в том числе, пролиферативную активность клеток в скаффолде или БМКП (рис. 5,b). Способ основан на прижизненном окрашивании ядер флуорохромом Hoechst 3334, проведении широкопольной флуоресцентной микроскопии в 10 полях зрения на различной глубине с применением функции Z-stack, последующим подсчетом ядер клеток на сшитых Z-stack микрофотоснимках и пересчетом количества клеток на $1 \mathrm{~mm}^{3}$. Показано, что таким образом можно оценить пролиферативную активность клеток в структуре скаффолдов/БМКП [10]. Представленный способ позволяет проводить и сравнительные исследования плотности распределения клеток, инкапсулированных в скаффолды и БМКП с трехмерной структурой, и оценку их жизнеспособности при использовании дополнительных флуорохромов для идентификации ядер мертвых клеток (например, TO-PRO 3 Ready Flow ${ }^{\mathrm{TM}}$ ) [13].

\section{Заключение}

Проведенные исследования показали, что использование широкопольной флуоресцентной микроскопии позволяет преодолеть большинство ограничений при исследовании различных материалов, скаффолдов и БМКП. ШФМ в доклинических исследованиях (in vitro) дает возможность осуществить прижизненную комплекс- ную характеристику взаимодействия поверхностнозависимых клеток с исследуемыми объектами биомедицинского назначения без их разрушения и повреждения самих клеток. Важнейшим свойством метода ШФМ является возможность анализа характеристик как прозрачных, так и непрозрачных объектов, проведение как качественного, так и количественного анализа. Полученные результаты демонстрируют широкие возможности ШФМ и доступность этого метода.

\section{Финансирование работы}

Работа выполнена при поддержке Российского научного фонда (№ 18-13-00434).

\section{Конфликт интересов}

Авторы заявляют, что у них нет конфликта интересов.

\section{Список литературы}

[1] Добровольская И.П., Дресвянина Е.Н., Юденко А.Н., Попрядухин П.В., Иванькова Е.М., Юдин В.Е. // Биофизика и медицинская физика. 2014. Т. 4. № 206. С. 74-86. [Dobrovolskaya I.P., Dresvyanina E.N., Yudenko A.N., Popryadukhin P.V., Ivankova E.M., Yudin V.E. // Biophysics and Medical Phys. 2014. Vol. 4. N 206. P. 74-86.]

[2] Hanawa T. // Front. Bioeng. Biotechnol. 2019. Vol. 7. P. 170. DOI:10.3389/fbioe.2019.00170

[3] Davachi S.M., Kaffashi B. // Polymer Plastics Technol. Eng. 2015. Vol. 54. P. 54944-54967. DOI:10.1080/03602559.2014.979507

[4] Richbourg N.R., Peppas N.A., Sikavitsas V.I. // J. Tissue Eng. Regenerative Medicine. 2019. Vol. 13. N 8. P. 1275-1293. DOI:10.1002/term.2859

[5] Кирилова И.А., Садовой М.А., Подорожсная В.Т. // Хирургия позвоночника. 2012. № 3. С. 72-83. [Kirilova I.A., Sadovoy M.A., Podorozhnaja V.T. // Hir. Pozvonoc. 2012. N 3. P. 72-83.] 
[6] Neto A.S., Ferreira J.M.F. // Materials. 2018. Vol. 11. P. 1702. DOI:10.3390/ma11091702

[7] Ливанова А.А., Деев Р.В., Ризванов А.А. // Гены и клетки. 2015. T. 10. № 1. P. 115-127. [Livanova A.A., Deev R.V., Rizvanov A.A. // Genes and Cells. 2015. Vol. 10. N 1. P. $115-127$.

[8] Kovylin R.S., Baten'kin M.A., Kulikova T.I., Egorikhina M.N., Charikova I.N., Gusev S.A., Rubtsova Y.P., Mlyavykh S.G., Aleynik D.Y., Chesnokov S.A., Fedushkin I.L. // Chem. Select. 2019. Vol. 4. P. 4147-4155. DOI:10.1002/slct.201803810

[9] Fan C., Wang D.-A. // Tissue Eng. Part B: Reviews. 2017. Vol. 23. P. 451-461. DOI:10.1089/ten.teb.2016.0465

[10] Caliari S.R., Burdick J.A. // Nature Methods. 2016. Vol. 13. P. 405-414. DOI:10.1038/nmeth.3839

[11] Антонова Л.В., Севостьянова В.В., Сейбалиан В.Г., Матвеева А.М., Великанова Е.А., Сергеева Е.А., Глушкова Т.В., Кривкина М.В., Насонова Е.О., Шишкова Д.К., Кудрявиева Ю.А., Барбараш О.Л., Барбараш Л.С. // Комплексные проблемы сердечно-сосудистых заболеваний. 2015. № 4. С. 34-41.

[12] Егорихина М.Н., Левин Г.Я., Алейник Д.Я., Чарыкова И.Н., Рубцова Ю.П., Соснина Л.Н., Давыденко Д.В. // Успехи современной биологии. 2018. T. 138. № 6. C. $273-282$. DOI: $10.7868 /$ S0042132418030055 [Egorikhina M.N., Levin G.Ya., Aleynik D.Ya., Charykova I.N., Rubtsova Y.P., Sosnina L.N., Davydenko D.V. // Biol. Bull. Rev. 2018. Vol. 138. N 6. P. 273-282. DOI: 10.7868/S0042132418030055]

[13] Egorikhina M.N., Aleynik D.Y., Rubtsova Y.P., Levin G.Y., Charykova I.N., Semenycheva L.L., Bugrova M.L., Zakharychev E.A. // Bioactive Materials. 2019. Vol. 4. P. 334-345. DOI:10.1016/j.bioactmat.2019.10.003 